\section{Physical Properties of Glass Ionomer Cement Containing Pre- Reacted Spherical Glass Fillers}

\author{
Piyaphong Panpisut ${ }^{10}$, Naruporn Monmaturapoj ${ }^{2}{ }^{(0)}$, Autcharaporn Srion ${ }^{3(\mathbb{D})}$, \\ Arnit Toneluck ${ }^{1}$, Prathip Phantumvanit ${ }^{10}$
}

'Faculty of Dentistry, Thammasat University, Pathum Thani, Thailand ${ }^{2}$ Assistive Technology and Medical Devices Research Center (A-MED), National Science and Technology Development Agency, Pathum Thani, Thailand

${ }^{3}$ National Metal Materials Technology Center (MTEC), National Science and Technology Development Agency, Pathum Thani, Thailand

Correspondence: Piyaphong Panpisut, Faculty of Dentistry, 99 Moo 18, T. Klong 1, A. Klongluang, Pathum Thani, 12121 Thailand. Tel: +66-891613189. e-mail: panpisut@staff.tu.ac.th

Key Words: pre-reacted glass, spherical glass fillers, fluoride release, compressive strength, biaxial flexural strength.

\section{Introduction}

Dental amalgam has been widely used as the main restorative materials due to its low cost, ease of manipulation and placement, good durability, and long historical record of safety (1). However, the use of dental amalgam will be decreased due to the Minamata Convention on Mercury in 2013 to avoid the risk of mercury contamination to the environment. Dental composites are considered suitable as alternative direct restorative materials, but they require complicated and highly sensitive placing techniques. The error occurred during composite placement could potentially lead to marginal leakage at tooth-composite interface (2). This may ultimately cause bacterial microleakage and secondary caries, which is the major reason of composite restoration failure (3). Glass ionomer cements (GICs) could be used for high caries risk patients due primarily to its ability to release fluoride. GICs however exhibit lower mechanical properties compared to dental composites and dental amalgam. This may lead to the suboptimal performance of GICs restorations in high load-bearing areas. It has been shown that the common reason for the GICs restoration failure was material fracture or chipping (4). Additionally, the reported survival rate at 10 year of GICs restorations was $37 \%$ whereas that of resin composites and dental amalgam were $43 \%$ and $51 \%$ respectively (5).

The previous study showed that the use of powder phase contained spherical pre-reacted glass fillers (SPG) (diameter $\sim 10 \mu \mathrm{m}$ ) enhanced mechanical properties of conventional GICs (6). It was proposed that the addition of SPG fillers may help increase surface area to encourage the interaction between glass fillers and polyacrylic acid (7). This could potentially help to promote the formation of continuous cross-link of polyacrylate salts and increase mechanical strength of the cement. It was also demonstrated that the reduction of filler size in GICs could increase the mechanical properties and the release of fluoride (8).

The main component in liquid phase of conventional GICs is polyacrylic acid (PAA). The structure and composition of PAA affected physical and mechanical properties of the materials (9). For example, the conformation and flexibility of polyelectrolyte chains in polyacrylate salt matrix influenced the degree of polymer cross-link and water movement across the cement during cement maturation. Additionally, it is known that water is essential for acidbase neutralization reaction, which enable the release of fluoride and other ions from fluoro-alumino-silicate glass. The degree of acid-base reaction also affected the amount of unreacted glass particles that act as reinforcing fillers that enhance mechanical strength of GICs (10). The aim 
of this study was therefore to assess the effect of using the different liquid phase of conventional GICs on cement maturation, fluoride release, and mechanical properties of experimental GICs containing SPG fillers. The null hypothesis was that the use of different liquid phase and SPG fillers showed no significant effect on the properties of the experimental GICs.

\section{Material and Methods}

\section{Glass Synthesis and Specimen Preparation}

Fluoroaluminosilicate glass fillers consisting of $\mathrm{SiO}_{2}-$ $\mathrm{Al}_{2} \mathrm{O}_{3}-\mathrm{CaF}_{2}-\mathrm{ZrO}_{2}$ as the glass network was prepared according to the previous study (6). The prepared glass was mixed with $2 \mathrm{wt} \%$ of Fuji IX Universal liquid (GC Corporation, Tokyo, Japan) to produce pre-reacted glass fillers. The glass fillers were ground for $3 \mathrm{~h}$ and subsequently sprayed the slurry using a spray dryer (B-290 Büchi Mini Spray Dryer, Büchi, Flawil, Switzerland) with an inlet temperature of drying air at $200{ }^{\circ} \mathrm{C}$ (outlet temperature of

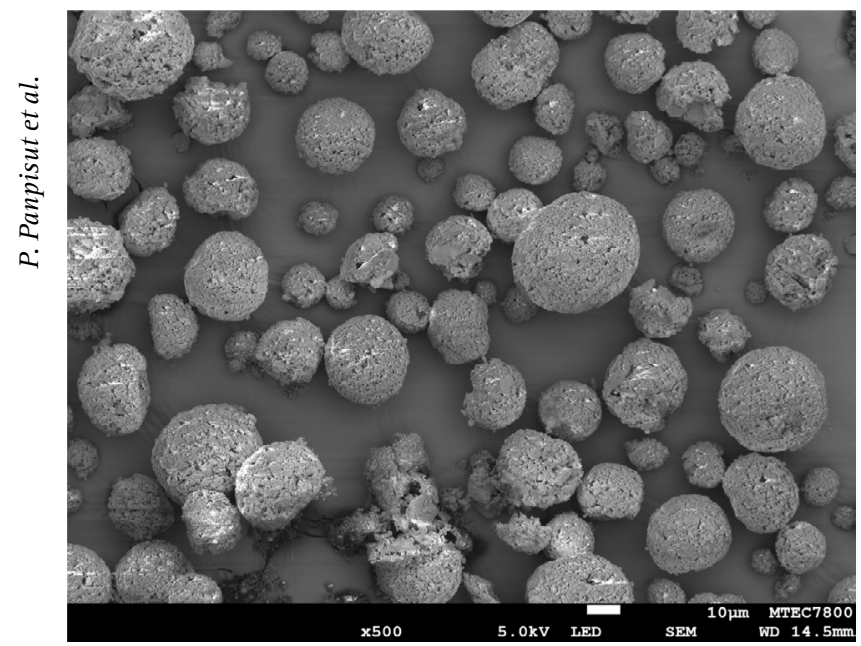

Figure 1. SEM image of pre-reacted spherical glass fillers. approximately $85-100{ }^{\circ} \mathrm{C}$ ). The average particle diameter of spherical fillers after spray-dried was approximately 10-20 $\mu \mathrm{m}$ (Fig. 1). The pre-reacted fillers of spherical shape were mixed with pre-reacted fillers of irregular shape to maximize filler packing at 60:40 weight ratio. The SPG fillers were mixed with liquid phase of Fuji IX Universal, Ketac Universal, and Riva Self Cure (Table 1) at the powder to liquid ratio (PLR) of 2.5:1. A pilot study demonstrated the SPG fillers can be mixed homogenously with liquid phase at PLR of 2.5:1.

\section{Cement Maturation Using FTIR}

An attenuated total reflection-Fourier transform IR (ATR-FTIR, Nicolet i5, Thermo Fisher Scientific, Massachusetts, USA) was employed to assess maturation process of GICs at early time. The materials were mixed using a plastic spatula within $20 \mathrm{~s}$ and placed in a metal circlip (1 $\mathrm{mm}$ in diameter and $1 \mathrm{~mm}$ in thickness) on the ATR diamond and covered by an acetate sheet. Then, the FIR spectra at a region of 700-1800 $\mathrm{cm}^{-1}$ with the resolution of $4 \mathrm{~cm}^{-1}$ were recorded from the bottom surface of the specimens for $10 \mathrm{~min}$.

\section{Fluoride Release}

Powder and liquid phases of each material were weighted using a four-digit balance and hand mixed using a plastic spatula within $2 \mathrm{~min}$. The mixed paste was immediately placed in a metal circlip (10 $\mathrm{mm}$ in diameter and $1 \mathrm{~mm}$ in thickness) $(\mathrm{n}=3)$. The specimens were left for curing in an incubator at the controlled temperature of 37 ${ }^{\circ} \mathrm{C}$ for $1 \mathrm{~h}$. They specimens were then removed from the ring and placed in a tube containing $5 \mathrm{~mL}$ of deionized water and incubated at $37{ }^{\circ} \mathrm{C}$. The storage solution was collected at each time point $(1,2,3,4,5$ days and 1,2,3, and 4,5,6,7,8 weeks) for analysis and replaced with a fresh solution. The collected solution was mixed with TISAB III (Orion ionplus, Thermo Scientific, MA, USA) with a volume

Table 1 . The composition of materials used in the current study

\begin{tabular}{|c|c|c|c|c|c|}
\hline Materials & Abbreviations & Components & $\begin{array}{l}\text { Recommended } \\
\text { powder to liquid } \\
\text { ratio (mass ratio) }\end{array}$ & Suppliers & $\begin{array}{l}\text { Lot } \\
\text { number }\end{array}$ \\
\hline $\begin{array}{l}\text { Fuji IX } \\
\text { Universal } \\
\text { (Shade A3) }\end{array}$ & Fuji IX & $\begin{array}{c}\text { Liquid: polyacrylic acid, Polybasic, polycarboxylic acid } \\
\text { Powder: Fluoro-alumino-silicate glass }\end{array}$ & $3.6: 1$ & $\begin{array}{l}\text { GC corporation, } \\
\text { Tokyo, Japan }\end{array}$ & 1506031 \\
\hline $\begin{array}{l}\text { Ketac } \\
\text { Universal } \\
\text { (Shade A3) }\end{array}$ & Ketac & $\begin{array}{c}\text { Liquid: copolymer of acrylic acid-maleic acid } \\
\text { 35\%-55\%, water 40\%-55\%, tartaric acid 5\%-10\% } \\
\text { Powder: glass powder } 80 \%-90 \% \text {, copolymer } \\
\text { of acrylic acid-maleic acid 1\%-6\% }\end{array}$ & $3: 1$ & $\begin{array}{c}\text { 3M ESPE; St } \\
\text { Paul, MN, USA }\end{array}$ & 3419923 \\
\hline $\begin{array}{l}\text { Riva Self cure } \\
\text { (Shade A3) }\end{array}$ & Riva & $\begin{array}{l}\text { Liquid: polyacrylic acid 20\%-30\%, tartaric } \\
\text { acid 10\%-15\%, remainder water } \\
\text { Powder: fluoroaluminosilicate glass 90\%- } \\
\text { 95\%, polyacrylic acid 5\%- } 10 \%\end{array}$ & $4.7: 1$ & $\begin{array}{l}\text { SDI, Victoria, } \\
\text { Australia }\end{array}$ & $11144991 \mathrm{~V}$ \\
\hline
\end{tabular}


ratio of 1:10 to measure concentration of fluoride ion in the solution using fluoride specific ion electrode (Orion Versa Star Pro, Thermo Scientific, MA, USA). Fluoride calibration standards at $0.1,1,10$, and 100 fluoride ppm were prepared using standard fluoride solution (Orion ionplus, Thermo Scientific). The cumulative fluoride ion release $\left(C_{F}\right)$ was calculated using the following equation.

$$
C_{F}=\sum{ }_{0}^{t} F_{t}
$$

\section{Equation 1}

Where $C_{F}$ is the cumulative fluoride ion release $(\mathrm{ppm})$, is the amount of fluoride (ppm) at time t. Then, the modified Fickian diffusion equation (Equation 2) was employed to assess fluoride releasing kinetic.

$$
\Delta F_{t}=\left(\Delta F_{\max }\right) 2 \sqrt{\frac{D_{F} t}{\pi l^{2}}}
$$

\section{Equation 2}

Where $\Delta \mathrm{F}_{\mathrm{t}}$ and $\Delta \mathrm{F}_{\text {max }}$ is the cumulative release and the maximum release at 8 weeks, $D_{F}$ is diffusion coefficient $\left(\mathrm{cm}^{2} / \mathrm{s}\right), \quad I$ is specimen thickness $(\mathrm{m})$. Commercial nonfluoride containing dental composite (Estelite Sigma Quick, Tukuyama Dental Corporation inc, Tokyo, Japan) was used as a control.

\section{Compressive Strength (CS)}

Glass ionomer cements were mixed and placed in a cylindrical stainless steel mould ( $6 \mathrm{~mm}$ in height and $4 \mathrm{~mm}$ in diameter)( $n=6)$ for compressive strength measurement. The specimens were left in an incubator at the controlled temperature of $37{ }^{\circ} \mathrm{C}$ for $1 \mathrm{~h}$. They were then removed, trimmed, and immersed in a tube containing $5 \mathrm{~mL}$ of deionized water in an incubator at $37^{\circ} \mathrm{C}$ for $23 \mathrm{~h}$ prior to the compressive strength testing. The test was performed using the universal testing machine (Intron 4502, Wycombe, UK) equipped with the $10 \mathrm{kN}$ load cell at a crosshead speed of $1 \mathrm{~mm} / \mathrm{min}$. Compressive strength (,Pa) was calculated using the following equation.

Equation 3

$$
C S=\frac{F}{\pi r^{2}}
$$

Where is load at failure $(\mathrm{N}), \mathrm{r}$ is radius of specimen $(\mathrm{m})$. Additionally, compressive modulus (CE, Pa) was calculated using the following equation.

$$
C E=\frac{F / \pi r^{2}}{\Delta L / L_{0}}
$$

Equation 4

Where $\Delta \mathrm{L}$ and $\mathrm{L}_{0}$ are change in length $(\mathrm{m})$ and original length $(m)$ of specimens respectively.

\section{Biaxial Flexural Strength (BFS)}

Specimens were mixed and placed in a metal circlip (1 $\mathrm{mm}$ in thickness and $10 \mathrm{~mm}$ in diameter). They were then covered with an acetate sheet under the glass slabs and left in an incubator for $1 \mathrm{~h}$. The specimens were then removed from the circlips and placed in a tube containing $5 \mathrm{~mL}$ of deionized water and incubated at $37^{\circ} \mathrm{C}$ for $23 \mathrm{~h}$. BFS was tested using ball-on-ring testing jig under a universal testing machine with a crosshead speed of $1 \mathrm{~mm} / \mathrm{min}$. $\mathrm{BFS}(\mathrm{Pa})$ was obtained using the following equation (11).

$$
\mathrm{BFS}=\frac{F}{d^{2}}\left\{(1+v)\left[0.485 \ln \left(\frac{r}{d}\right)+0.52\right]+0.48\right\}
$$

\section{Equation 5}

Where is the load at failure $(\mathrm{N}), d$ is the specimen's thickness $(\mathrm{m})$, is the radius of circular support $(\mathrm{m})$, and $r$ is Poison's ratio (0.3). Additionally, biaxial flexural modulus (BFM) was calculated using the following equation.

$$
B F M=\left(\frac{\Delta H}{\Delta W_{c}}\right) \times\left(\frac{\beta_{c} d^{2}}{q^{3}}\right)
$$

\section{Equation 6}

Where BFM is biaxial flexural modulus of the specimen (Pa), $\frac{\Delta H}{\Delta W_{c}}$ is rate of change of load with regards to central deflection or gradient of force versus displacement curve $(\mathrm{N} / \mathrm{m}), \beta_{\mathrm{c}}$ is center deflection junction (0.5024), q is ratio of support radius to the radius of disc, and $v$ is Poison's ratio $(0.3)$.

\section{Statistical Analysis}

Data presented in this study were mean with SD. Data were analyzed using SPSS for Mac version 26 (IBM, New York, USA). Homogeneity of variance of the results was initially examined using Levene test. One-way analysis of variance (ANOVA) followed by Tukey post-hoc multiple comparison was used when variances between groups were equal. Alternatively, Krasskal-Wallis test followed by post-hoc Dunnett T3 test was employed when variances between groups were not equal. Furthermore, the effect 
of using different liquid phases (Ketac, Riva, Fuji IX) and types of fillers (SPG and commercial glass fillers) on properties of GICs was examined using two-way ANOVA. The significance value was set at $p=0.05$. Post-hoc power analysis was assessed using $G^{*}$ Power version 3.1.9.4 for Mac (University of Dusseldorf, Düsseldorf, Germany), which indicated that the sample size used in each test gave power $>0.99$ at $\alpha=0.05$.

\section{Results}

\section{Cement Maturation Using FIIR}

FTIR results obtained from all GIC liquids were relatively similar to each other (Fig. 2A). Peaks attributable to polyacrylic acid (PAA) at $1700 \mathrm{~cm}^{-1}$ (C=0 stretch), $1452 \mathrm{~cm}^{-1}$ (C-H scissor), and $1249 \mathrm{~cm}^{-1}$ (C-O stretch) were detected (Fig. 2A). Peak representing water component $\left(1630 \mathrm{~cm}^{-1}\right.$, $0-\mathrm{H}$ stretch) was also obtained. For all materials, $\mathrm{C}=0$ stretch of PAA was decreased upon mixing liquid with powder phase (Fig. 2B-2G). The peaks representing polyacrylate salts with mono/divalent counter ions (approximately 1555 and 1631 $\left.\mathrm{cm}^{-1}\right)$ (12) was seen in all materials. However, these peaks were more clearly observed in Riva and Riva_M compared to other GICs (Fig. 2D and 2G).

\section{Fluoride Release}

The burst release of fluoride was observed in all GICs (Fig. 3A). The highest and lowest burst release at $24 \mathrm{~h}$ were obtained from Riva $(14.1 \pm 1.4 \mathrm{ppm})$ and Ketac_M $(4.0 \pm 0.2$ $\mathrm{ppm})$ respectively. The cumulative release of fluoride observed in all GICs increased linearly with square root of hour (R2>0.99). The result from two-way ANOVA indicated that using SPG filler increased diffusion coefficient of fluoride (DF) for GICs $(p<0.01)$. Type of liquid phase also affected DF of experimental GICs ( $p<0.01)$. Using Riva liquid showed significant highest DF (Riva_M, 1.65 $\times 10^{-9} \pm 0.01 \times 10^{-9}$ $\mathrm{cm}^{2} / \mathrm{s}$ ) compared with other experimental GICs (Fig. 3B). The lowest DF was obtained from Fuji IX $\left(1.19 \times 10^{-9} \pm 0.08 \times 10^{-9}\right.$ $\left.\mathrm{cm}^{2} / \mathrm{s}\right)$. Ketac_M $\left(1.40 \times 10^{-9} \pm 0.06 \times 10^{-9} \mathrm{~cm}^{2} / \mathrm{s}\right)$ and Fuji IX_M $\left(1.39 \times 10^{-9} \pm 0.02 \times 10^{-9} \mathrm{~cm}^{2} / \mathrm{s}\right)$ exhibited comparable DF to both Ketac $\left(1.34 \times 10^{-9} \pm 0.03 \times 10^{-9} \mathrm{~cm}^{2} / \mathrm{s}\right)(p=0.978)$ and Fuji IX ( $p=0.150)$.

The cumulative fluoride release (CF) of all GICs was significantly increased upon immersion time $(p<0.01)$ (Fig. 3C). The results indicated that using SPG fillers reduced CF of GICs at 8 weeks $(p<0.01)$. The average CF at 8 weeks obtained from experimental GICs (42 ppm) was lower than that of commercial GICs (51 ppm). Types of liquid phases also affected the CF of experimental GICs $(p<0.01)$.

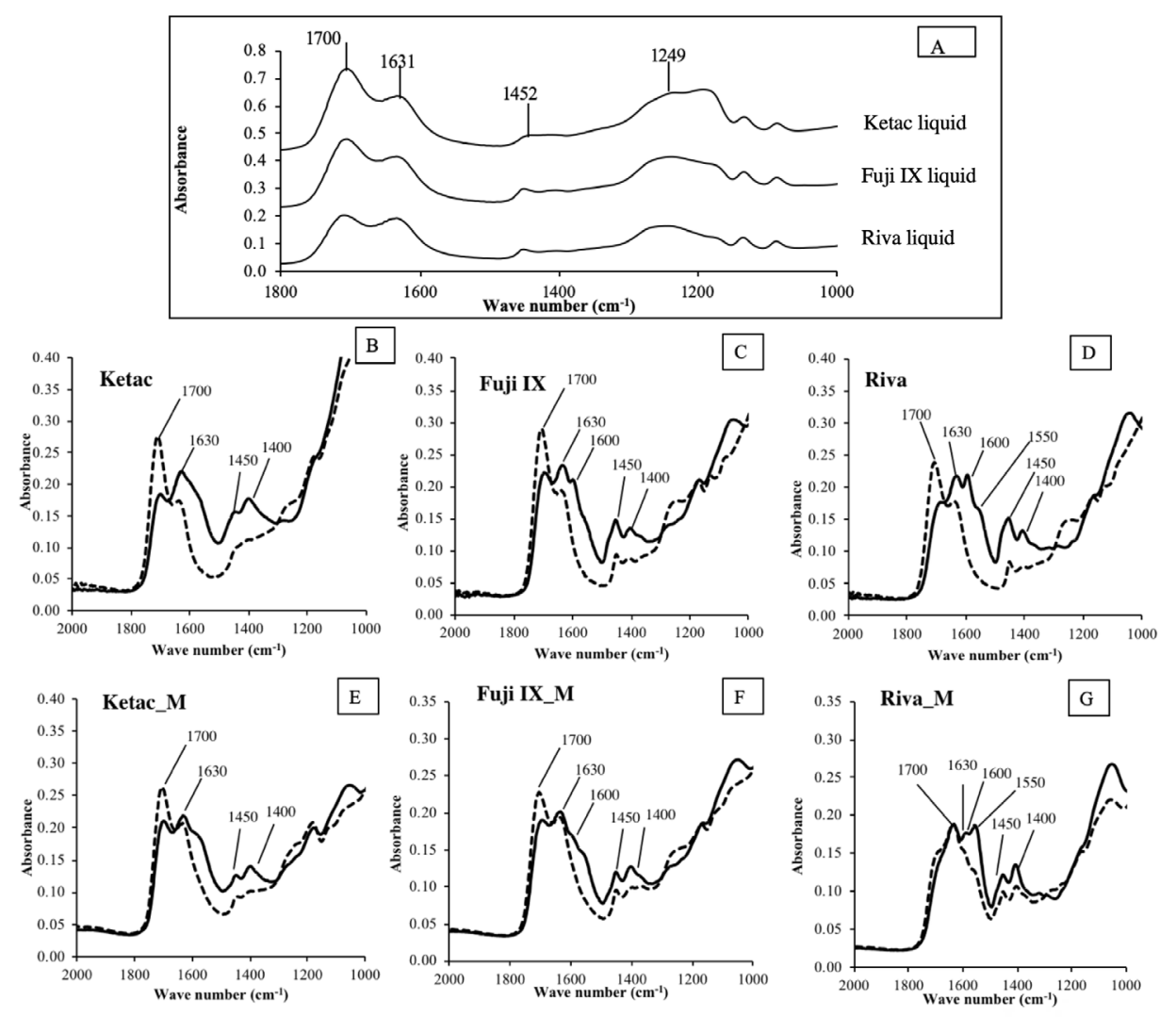

Figure 2. FTIR spectra of commercial liquid phases (A) and GICs after mixing immediately and 10 min after mixing (B-G). 
Riva groups exhibited highest CF at 8 weeks $(77 \pm 9$ ppm for Riva, $60 \pm 2$ ppm for Riva_M) which were significantly higher than both Ketac group ( $49 \pm 3$ ppm for Ketac, $27 \pm 1$ ppm for Ketac_M) and Fuji IX group (28 \pm 3 ppm for Fuji IX, 37 \pm 2 ppm for Fuji IX_M) $(\mathrm{p}<0.01)$.

\section{Compressive Strength (CS) and Compressive Modulus (CE)}

All materials except for Riva_M $(55 \pm 9 \mathrm{MPa})$ exhibited CS greater than $100 \mathrm{MPa}$ required by the ISO 9917-1:2007 (Fig. 4A). The highest CS was obtained from Ketac $(131 \pm 13$ $\mathrm{MPa})$ which was comparable to that of Ketac_M $(144 \pm 11$ $\mathrm{MPa})(\mathrm{p}=0.665)$, Riva $(123 \pm 15 \mathrm{MPa})(\mathrm{p}=0.975)$, Fuji IX $(123 \pm 28 \mathrm{MPa})(p=0.983)$, and Fuji IX_M $(128 \pm 8 \mathrm{MPa})$ $(p=0.895)$. The result from two-way ANOVA indicated that types of powder and liquid phases affected CS and CE of GICs $(p<0.01)$. The use of SPG filler reduced CS from 122 to $55 \mathrm{MPa}$ for Riva whereas the effect of using SPG filler on
CS of Ketac and Fuji IX was negligible. The highest CE was observed with Ketac $(5.6 \pm 0.5 \mathrm{GPa})$ followed by Ketac_M (5.6 $\pm 0.2 \mathrm{GPa})$, Riva (5.0 $\pm 0.4 \mathrm{GPa})$, Fuji IX $(5.1 \pm 0.2 \mathrm{GPa})$, Fuji IX_M $(4.9 \pm 0.2 \mathrm{GPa})$, and Riva $(5.0 \pm 0.4 \mathrm{GPa})$ (Fig. 4B). These moduli were significantly higher than the that of Riva_M $(3.1 \pm 0.6 \mathrm{GPa})(p<0.01)$. Additionally, the use of SPG fillers reduced compressive modulus for Riva.

\section{Biaxial Flexural Strength (BFS) and Biaxial Flexural Modulus (BFM)}

The highest and lowest BFS were obtained from Riva $(41.9 \pm 4.5 \mathrm{MPa})$ and Ketac (21.6 $\pm 2.2 \mathrm{MPa})$ (Fig. 4C). The results indicated that types of powder $(\mathrm{p}=0.039)$ and liquid phases $(p<0.01)$ affected both BFS and BFM of GICs. The use of SPG fillers in Riva reduced BFS of the material. However, the effect of using SPG fillers on the BFS of Ketac and Fuji IX was negligible. Riva_M $(28.1 \pm 1.5 \mathrm{MPa})$ exhibited significant lower BFS than Riva $(p<0.01)$. The BFS
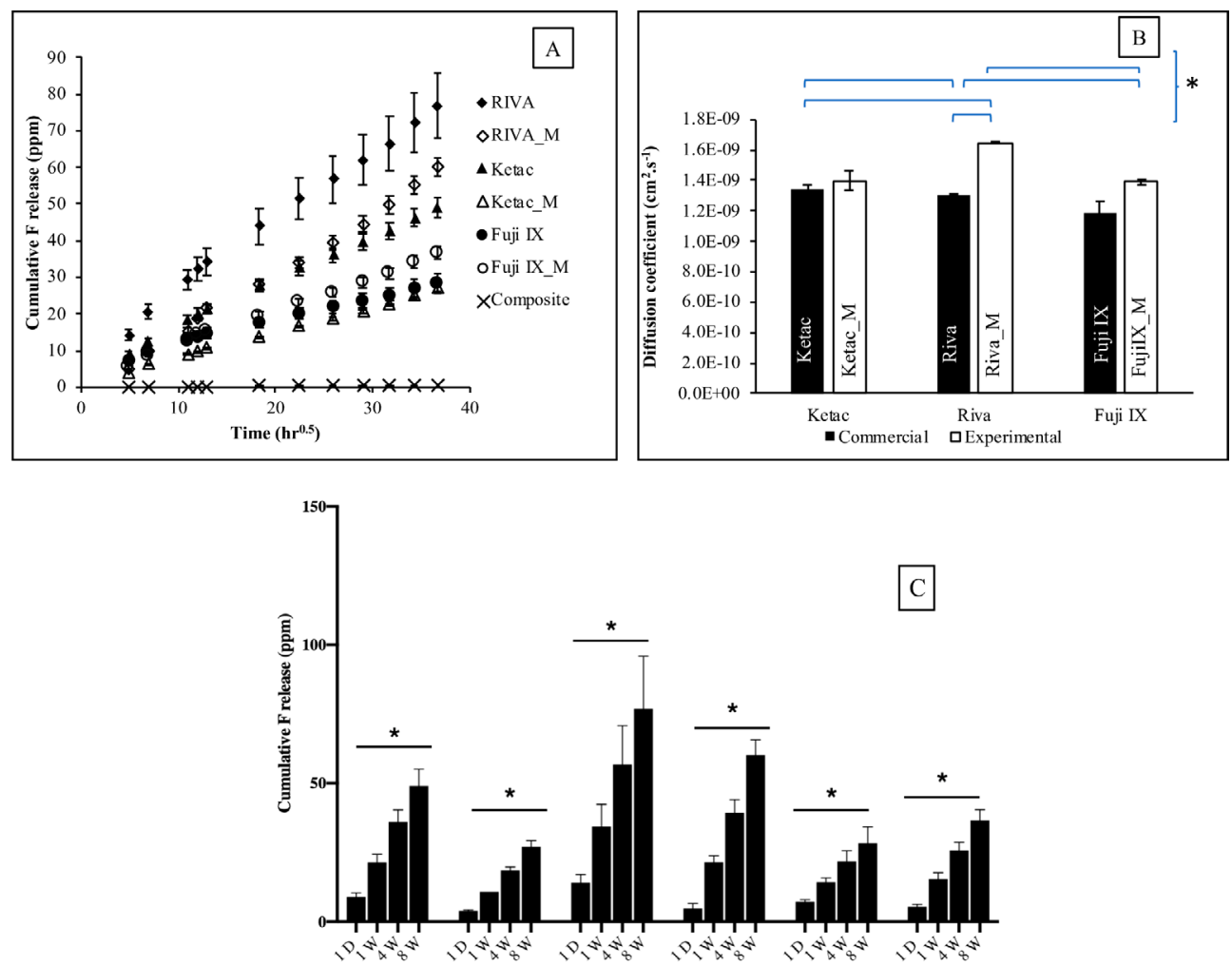

\begin{tabular}{|c|c|c|c|c|c|c|}
\hline Materials & Ketac & Ketac_M & Riva & Riva_M & Fuji IX & Fuji IX_M \\
\hline 1 day & $\begin{array}{c}9 \\
\text { (a) }\end{array}$ & $\begin{array}{c}4 \\
(b, c)\end{array}$ & 14 & $\begin{array}{c}5 \\
(\mathrm{a}, \mathrm{c})\end{array}$ & $\begin{array}{c}7 \\
(\mathrm{a}, \mathrm{c})\end{array}$ & $\begin{array}{c}5 \\
(\mathrm{a}, \mathrm{c})\end{array}$ \\
\hline 1 week & $\begin{array}{l}21 \\
\text { (a) }\end{array}$ & $\begin{array}{l}11 \\
\text { (b) }\end{array}$ & 34 & $\begin{array}{l}21 \\
\text { (a) }\end{array}$ & $\begin{array}{c}14 \\
(\mathrm{~b}, \mathrm{c})\end{array}$ & $\begin{array}{l}15 \\
\text { (c) }\end{array}$ \\
\hline 4 weeks & $\begin{array}{l}36 \\
\text { (a) }\end{array}$ & $\begin{array}{l}19 \\
\text { (b) }\end{array}$ & 57 & $\begin{array}{l}39 \\
\text { (a) }\end{array}$ & $\begin{array}{c}22 \\
(\mathrm{~b}, \mathrm{c})\end{array}$ & $\begin{array}{l}26 \\
\text { (c) }\end{array}$ \\
\hline 8 weeks & 49 & $\begin{array}{l}27 \\
\text { (a) }\end{array}$ & 77 & 60 & $\begin{array}{l}28 \\
\text { (a) }\end{array}$ & 37 \\
\hline
\end{tabular}

Figure 3. A: Fluoride releasing profile of all materials versus square root of hour (hr0.5). B: Diffusion coefficient of fluoride release (DF). C: Cumulative fluoride release (CF) at 1 day, 1 week, 4 weeks, and 8 weeks. Stars $\left(^{*}\right)$ indicate significant difference $(p<0.05)$. Same letters indicate no significant differences ( $p>0.05)$. Error bars are 95\% CI $(n=3)$ 
of Ketac $\_M(21.8 \pm 2.8 \mathrm{MPa})$ was comparable to that of Ketac $(p=1.00)$. Additionally, the BFS of Fuji IX_M $(30.3 \pm 2.1 \mathrm{MPa})$ was comparable to that of Fuji_IX $(24.0 \pm 5.3 \mathrm{MPa})(\mathrm{p}=0.095)$. The use of SPG fillers reduced BFM of GICs ( $p=0.011)$ whilst the use of different liquid phase showed negligible effect $(p=0.0801)$. BFM of experimental GICs was comparable to their commercial comparison ( $p>0.05$ )(Fig. 4D).

\section{Discussion}

The previous study assessed the effect of varying the ratio of irregular and spherical pre-reacted fillers on physical/mechanical properties GICs. The study used Fuji II liquid (GC corporation, Tokyo, Japan) as the liquid phase for experimental GICs (6). It is however known that the liquid phase from different commercial GICs may consist of varying molecular weight of polyacrylic acids and different level of water. The use of different liquid phase could therefore potentially affect the cement maturation, fluoride release, and mechanical properties of the experimental GICs.

\section{FTIR Studies}

The initial setting reaction of GICs is acid-base neutralization reaction occurred between the glass fillers
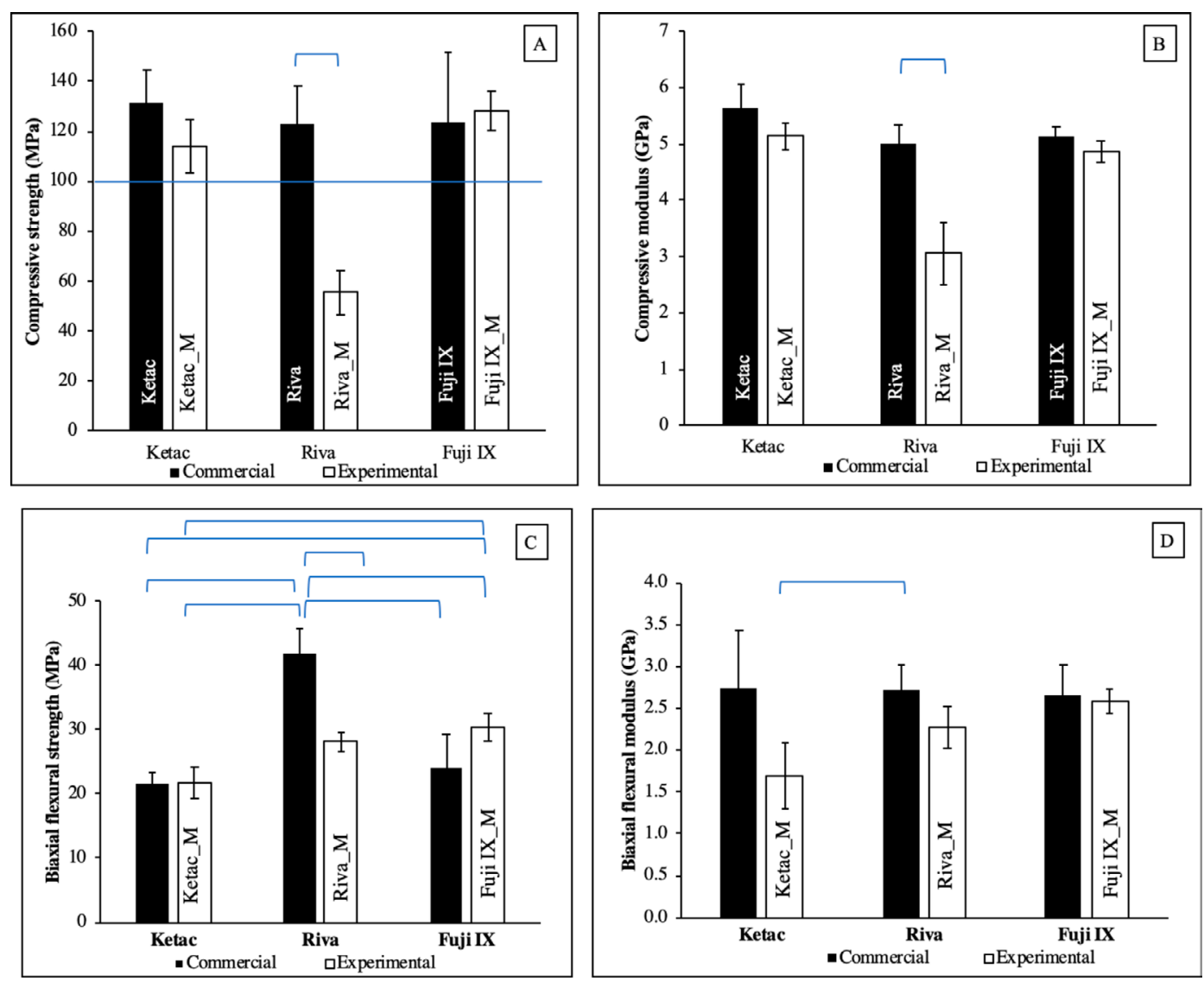

Figure 4. A: Compressive strength. B: Compressive modulus. C: Biaxial flexural strength. D: Biaxial flexural modulus of all materials after immersion in deionized water for $24 \mathrm{~h}$. Lines indicated significant difference $(\mathrm{p}<0.05)$. Error bars are 95\% CI $(\mathrm{n}=6)$ 
polyacrylic salts network formed in Riva_M.

\section{Fluoride Release}

It is expected that fluoride ion released from GICs may help promote anti-caries effects. The release of fluoride could enable the formation of the low soluble fluorohydroxyapatite (16) and affect the metabolism of cariogenic bacteria (17). The current study demonstrated that fluoride release of all GICs increased linearly with square root of time (h) indicating a diffusion-controlled release. This is consistent with the result from a previous study (18). The fluoride release can be demonstrated by modifying equation 2 .

$$
\Delta F=\Delta F_{0}+\Delta F_{\infty} \sqrt{\frac{2 D_{F} t}{\pi l^{2}}}
$$

Equation 7

Where ; the change in cumulative fluoride in the solution, ; early burst release, ; maximum change in the solution, DF; fluoride diffusion coefficient, $t$; time, 1 ; sample thickness. The burst release of fluoride may come from initial acid-base reaction and surface elution (19). The subsequent slow and sustain release could be due to the diffusion of fluoride from the slow acid-base neutralization reaction in the bulk of materials.

The use of Riva liquids as the liquid phase for experimental GICs enabled highest DF compared with other materials. Riva liquid may contain lower concentration of polyacrylic and high level of water compared with other liquid phases. This may lead to rapid acid-base neutralization reaction resulting in the high level of hydrophilic components in $\mathrm{GICs}(20)$. This may help to encourage water diffusion that can promote DF of the material (18).

The result in the current study demonstrated that the use of SPG fillers enhanced DF. The use of SPG fillers was expected to help increase the amount of free fluoride and the surface area for interaction with ionized PAA. This might therefore promote the diffusion and release of fluoride in the experimental GICs. However, the cumulative fluoride release (CF) of the experimental GICs was comparable or lower than that of the commercial materials. This indicated that the total amount of fluoride release was primarily governed by the initial fluoride consisted in the powder phase (21). Hence, the use of PLR of 2.5:1 in experimental $\mathrm{GICs}$, which was lowered than that of the commercial GICs (3:1 - 4.7:1), might limit the level of CF observed with experimental GICs.

\section{Compressive Strength (CS) and Compressive Modulus (CE)}

High mechanical properties of GICs are required to reduce the risk of restoration failure due to material fracture which is commonly observed with GICs restorations (22). Mechanical strength of GICs were governed by several factors including powder to liquid ratio, composition of materials, commercial brands, and the mixing conditions (23). The results in the current study demonstrated that mixing SPG with Fuji IX or Ketac liquids showed comparable CS and CE to commercial materials despite the PLR used in experimental GICs (2.5:1) was lower than that of the commercial materials (3.6:1 for Fuji IX, 4.7:1 for Ketac). In general, the use of low PLR may associate with high amount of water inside the cement matrix which may reduce mechanical properties of GICs (24). The possible reason for the high strength of Ketac_M and FujiIX_M may be due to the high surface area of spherical SPG fillers helped promote the interaction of glass and polyacrylic solution increasing the degree of cross-linking in the cements (6).

The use of SPG fillers reduced CS and CE when mixing with Riva liquid. The possible explanation could be that the liquid of Riva may contain high level of water that causes high solubility and low rigidity of the cement. The high level of water content may contribute to high level of fluoride release observed with Riva_M. This high solubility could however negatively affect the CS and CE of Riva_M. The strength of Riva_M was also lower than $100 \mathrm{MPa}$ required by BS EN ISO 9917-1 2007 Dentistry-Water-based cements. Part 1: Powder/liquid acid-based cement.

\section{Biaxial Flexural Strength (BFS) and Biaxial Flexural Modulus (BFM)}

Some studies proposed that three-point flexural test or biaxial flexural test are more suitable method to determine strength of GICs compared to compressive test (25). However, the compressive strength test is still required by the ISO standard. The use of SPG fillers as powder phase in Ketac and Fuji IX slightly increased BFS of the GICs. The possible explanation could be that high surface area of spherical fillers may help promote cross-link between glass and polyacid. The use of SPG fillers in Riva however decreased BFS of the materials, which was in agreement with the result from compressive strength test. Although the BFM between commercial GICs and experimental GICs was not significant different, the results showed that SPG reduced mean BFM of GICs.

Null hypothesis was rejected as the current study demonstrated that using different liquid phases and SPG fillers affected cement maturation, fluoride release, and strength of GICs. The use of SPG fillers enhanced DF but reduced $\mathrm{CF}$ of the materials. The use of Riva enabled highest DF but also resulted in lowest strength of experimental GICs. Mixing SPG with liquid phases of Ketac or Fuji IX exhibited CS and BFS comparable to commercial materials. 


\section{Resumo}

0 objetivo deste estudo foi avaliar o efeito de diferentes fases líquidas comerciais (Ketac, Riva e Fuji IX) e o uso de partículas esféricas de vidro pré-reagido $(\mathrm{SPG})$ na maturação do cimento, liberação de flúor, força de compressão (CS) e resistência biaxial à flexão (BFS) de cimentos de ionômero de vidro (GICs) experimentais. Os GICs experimentais (Ketac_M, Riva_M, FujilX_M) foram preparados pela mistura de partículas SPG com fases líquidas comerciais usando a proporção de pó para massa líquida de 2,5: 1. 0 FTIR-ATR foi usado para avaliar a maturação dos GICs. 0 coeficiente de difusão do flúor (DF) e a liberação cumulativa de flúor (CF) em água deionizada foram determinados usando o eletrodo específico do ion fluoreto $(n=3)$. CS e BFS em 24 h também foram testados $(n=6)$. GICs comerciais foram usados como comparações. Riva e Riva_M exibiram rápida formação de sal de poliacrilato. Os maiores DFe CF foram observados com Riva_M $\left(1,65 \times 10^{-9} \mathrm{~cm}^{2} / \mathrm{s}\right)$ e Riva (77 ppm), respectivamente. 0 uso de partículas SPG melhorou o DF de GICs em média de $\sim 2,5 \times 10^{-9} \mathrm{~cm}^{2} / \mathrm{s}$ a $3,0 \times 10^{-9} \mathrm{~cm}^{2} / \mathrm{s}$, mas reduziu o CF dos materiais em média de $\sim 51 \mathrm{ppm}$ a $\sim 42$ ppm. 0 CS e BFS de Ketac_M (144 e 22 MPa) e Fuji IX_M (123 e 30 $\mathrm{MPa}$ ) foram comparáveis aos materiais comerciais. Usar SPG com Riva reduziu significativamente CS e BFS de $123 \mathrm{MPa}$ para $55 \mathrm{MPa}$ e $42 \mathrm{MPa}$ para $28 \mathrm{MPa}$, respectivamente. 0 uso de SPG partículas melhorou o DF, mas reduziu o CF dos GICs. 0 uso de partículas SPG com líquidos Ketac ou Fuji IX proporcionou resistência comparável aos materiais comerciais.

\section{Acknowledgements}

The authors would like to express their heartfelt gratitude to Faculty of Dentistry, Thammasat University Research Grant (ID: 1/2560) for supporting this study.

\section{References}

1. Austin R, Eliyas S, Burke FJ, Taylor P, Toner J, Briggs P. British society of prosthodontics debate on the implications of the minamata convention on mercury to dental amalgam-should our patients be worried? Dent Update 2016;43:8-10,2-4,6-8.

2. Nedeljkovic I, Teughels W, De Munck J, Van Meerbeek B, Van Landuyt $\mathrm{KL}$. Is secondary caries with composites a material-based problem? Dent Mater 2015;31:e247-277.

3. Nedeljkovic I, De Munck J, Vanloy A, Declerck D, Lambrechts P, Peumans $M$, et al. Secondary caries: prevalence, characteristics, and approach. Clin Oral Investig 2019.

4. Lohbauer U. Dental Glass Ionomer Cements as Permanent Filling Materials? - Properties, Limitations and Future Trends. Materials 2010;3:76.

5. Burke FJT, Lucarotti PSK. The ultimate guide to restoration longevity in England and Wales. Part 3: Glass ionomer restorations - time to next intervention and to extraction of the restored tooth. BDJ 2018;224:865-874.

6. Monmaturapoj N, Soodsawang W, Tanodekaew S. Enhancement effect of pre-reacted glass on strength of glass-ionomer cement. Dent Mater J 2012;31:125-130.

7. Ilie N. Maturation of restorative glass ionomers with simplified application procedure. J Dent 2018;79:46-52.

8. Najeeb S, Khurshid Z, Zafar MS, Khan AS, Zohaib S, Marti JM, et al. Modifications in glass ionomer cements: nano-sized fillers and bioactive nanoceramics. Int J Mol Sci 2016;17:1134.

9. Berg MC, Benetti AR, Telling MTF, Seydel T, Yu D, Daemen LL, et al. Nanoscale mobility of aqueous polyacrylic acid in dental restorative cements. ACS Appl Mater Interfaces 2018;10:9904-9915.

10. Moshaverinia A, Roohpour N, Chee WWL, Schricker SR. A review of powder modifications in conventional glass-ionomer dental cements. J. Mater. Chem. 2011;21:1319-1328.

11. Panpisut $\mathrm{P}$, Liaqat $\mathrm{S}$, Zacharaki E, Xia W, Petridis $\mathrm{H}$, Young AM. Dental composites with calcium / strontium phosphates and polylysine. PLoS One 2016;11:e0164653.

12. Khaghani M, Doostmohammadi A, Golniya Z, Monshi A, Arefpour AR. Preparation, physicochemical characterization, and bioactivity evaluation of strontium-containing glass ionomer cement. ISRN Ceramics 2013;2013:1-7.

13. Nicholson JW. Maturation processes in glass-ionomer dental cements. Acta Biomater Odontol Scand 2018;4:63-71.

14. Roberts HW, Berzins DW. Early reaction kinetics of contemporary glassionomer restorative materials. J Adhes Dent 2015;17:67-75.

15. Young AM, Rafeeka SA, Howlett JA. FTIR investigation of monomer polymerisation and polyacid neutralisation kinetics and mechanisms in various aesthetic dental restorative materials. Biomaterials 2004;25:823-833.

16. Tantbirojn D, Feigal RJ, Ko CC, Versluis A. Remineralized dentin lesions induced by glass ionomer demonstrate increased resistance to subsequent acid challenge. Quintessence Int 2006;37:273-281.

17. Chau NP, Pandit S, Cai JN, Lee MH, Jeon JG. Relationship between fluoride release rate and anti-cariogenic biofilm activity of glass ionomer cements. Dent Mater 2015;31:e100-108.

18. Yan Z, Sidhu SK, Mahmoud GA, Carrick TE, McCabe JF. Effects of temperature on the fluoride release and recharging ability of glass ionomers. Oper Dent 2007;32:138-143.

19. Davis HB, Gwinner F, Mitchell JC, Ferracane JL. Ion release from, and fluoride recharge of a composite with a fluoride-containing bioactive glass. Dent Mater 2014;30:1187-1194.

20. Alhalawani AMF, Curran DJ, Boyd D, Towler MR. The role of poly(acrylic acid) in conventional glass polyalkenoate cements. J Polym Eng 2016;36:221-237.

21. Neelakantan $P$, John $S$, Anand S, Sureshbabu N, Subbarao C. Fluoride release from a new glass-ionomer cement. Oper Dent 2011;36:80-85.

22. Heintze SD, llie N, Hickel R, Reis A, Loguercio A, Rousson V. Laboratory mechanical parameters of composite resins and their relation to fractures and wear in clinical trials-A systematic review Siegward. Dent Mater 2017;33:e101-e114.

23. Fonseca RB, Branco CA, Quagliatto PS, Goncalves Lde $\mathrm{S}$, Soares CJ, Carlo $\mathrm{HL}$, et al. Influence of powder/liquid ratio on the radiodensity and diametral tensile strength of glass ionomer cements. J Appl Oral Sci 2010;18:577-584.

24. Bueno LS, Silva RM, Magalhaes APR, Navarro MFL, Pascotto RC, Buzalaf MAR, et al. Positive correlation between fluoride release and acid erosion of restorative glass-ionomer cements. Dent Mater 2019;35:135-143.

25. Garoushi SK, He J, Vallittu PK, Lassila LVJ. Effect of discontinuous glass fibers on mechanical properties of glass ionomer cement. Acta Biomater Odontol Scand 2018;4:72-80.

Received December 4, 2019 Accepted February 10, 2020 